\title{
Coronary Artery Disease Prediction Using Decision Trees and Multinomial Naïve Bayes with k-Fold Cross Validation
}

\author{
Endang S Kresnawati ${ }^{1}$, Yulia Resti ${ }^{2 *}$, Bambang Suprihatin ${ }^{3}$, M. Rendy Kurniawan ${ }^{4}$, \\ Widya Ayu Amanda 5 \\ 1,2,3,4,5Jurusan Matematika, FMIPA, Universitas Sriwijaya, Indonesia \\ *yulia_resti@mipa.unsri.ac.id
}

\begin{abstract}
Abstrak
Penyakit arteri koroner (coronary artery disease) menjadi penyebab utama kematian penduduk di dunia setidaknya selama dua dekade (2000-2019) dan mengalami peningkatan kematian terbesar dalam rentang waktu tersebut dibandingkan dengan penyebab kematian lainnya. Keberhasilan memprediksi penyakit arteri koroner secara dini berdasarkan data medis bermanfaat bagi pasien dan juga bagi kestabilan perekonomian negara. Tujuan penelitian ini adalah memprediksi penyakit arteri koroner jantung dengan mengimplementasikan dua metode statistical learning yaitu Multinomial Naïve Bayes dan pohon keputusan dengan validasi silang 10-fold, dimana variabel-variabel numerik didiskritisasi untuk memperoleh variabel-variabel kategorik. Hasil penelitian menunjukkan bahwa metode Pohon Keputusan memiliki kinerja yang lebih baik dibandingkan metode Multinomial Naïve Bayes dalam memprediksi penyakit arteri koroner. Ukuran kinerja metode Pohon Keputusan memperoleh tingkat akurasi 99,63\%, sensitivitas $100 \%$, spesifisitas 99,33\%, presisi 99,23\%, dan nilai prediksi negatif (NPV) $100 \%$. Ukuranukuran ini mengindikasikan bahwa metode Pohon Keputusan layak digunakan untuk memprediksi penyakit arteri coroner, termasuk data independent berupa data penyakit arteri coroner lainnya dengan variable predictor yang sama. Hasil penelitian ini juga menunjukkan bahwa perbedaan rujukan dengan penelitian-penelitian sebelumnya dalam mendiskritisasi variabel numerik mampu meningkatkan kinerja metode dalam memprediksi penyakit arteri coroner.
\end{abstract}

Kata kunci: Penyakit Arteri Koroner, Kinerja, Prediksi.

\begin{abstract}
Coronary artery disease has been the leading cause of death in the world population for at least two decades (2000-2019) and has experienced the largest increase in mortality in that time span compared to other causes of death. The success of predicting coronary artery disease early based on medical data is not only beneficial for patients, but also beneficial for the stability of the country's economy. This paper discusses the prediction of coronary artery disease risk by implementing two statistical learning methods, namely Multinomial Naïve Bayes and Decision Tree with 10-fold cross validation, where numerical variables are discretized to obtain categorical variables. The results showed that the Decision Tree method has better performance than the Multinomial Naïve Bayes method in predicting coronary artery disease. The performance measure of the Decision Tree method obtained an accuracy rate of $99.63 \%, 100 \%$ sensitivity, $99.33 \%$ specificity, $99.23 \%$ precision, and 100\% Negative Prediction Value. These measures indicate that the Decision Tree method is appropriate for predicting coronary artery disease, including independent data (other coronary artery disease data with the same predictor variables). The results of this study
\end{abstract}


also show that the different references to previous studies in discretizing numerical variables can improve the performance of the method in predicting coronary artery disease.

Keywords: Coronary Artery Disease, Performance, Prediction.

Received: Mei 3, 2021/ Accepted: Juli 28, 2021/ Published Online: Juli 29, 2021

\section{PENDAHULUAN}

Coronary artery disease (CAD) or also called heart disease (heart disease) occurs due to decreased blood flow to the heart muscle due to plaque buildup (atherosclerosis) in the heart arteries (Mendis et al., 2015). Another name for this disease is coronary heart disease or ischemic heart disease (Bhatia, 2010). In some literature, this disease is also called cardiovascular (Purushottam et al., 2016; Chowdary et al., 2020). This disease has been the leading cause of death in the world's population for at least two decades (2000-2019) and has experienced the largest increase in deaths in that time span compared to other causes of death. In high-income countries, coronary artery disease has long been a major contributor to the overall disease burden, in addition to stroke and cancer. The burden of this disease is also increasing in middle-income countries, and also in low-income countries. The success of early detection of coronary artery disease based on medical data is not only beneficial for patients but also beneficial for economic stability (WHO, 2019).

Purushottam et al., (2016) predicted coronary artery disease using the same dataset, but they filled in the missing data using the AllPossible-MV algorithm (Alcalá-Fdez, et al., 2009; Alcalá-Fdez, et al., 2011). They proposed several machine learning methods, namely Support Vector Machine (SVM), Decision Tree C4.5 Algorithm, Neural Network (NN), PART, Multiple Layer Perceptron (MLP), Radial Basis Function (RBF), TSEAFS, and Efficient System. The highest level of accuracy achieved using the 10-fold cross-validation model was 86.3\% using the Efficient System method, followed by the RBF method (78.53\%), TSEAFS (77.45\%), NN (76.47\%), Algorithm C4.5 Decision Tree (73.53\%), PART (73.53\%), and SVM $(70.59 \%)$.

Chowdary et al. (2020) also predict coronary artery disease using the same dataset, but they change some of the categorical type data to numeric type. The machine learning methods they implement are quite a lot, namely Logistic Regression, Random Forest, Decision Tree, Gaussian Naïve Bayes, Binomial Nave Bayes, Multinomial Naïve Bayes, K-Nearest Neighbor, Artificial Neural Network, and Voting of Logistic Regression and K-Nearest Neighbor (VLRAKN). Their funding shows that the VLRAKN method has the highest level of accuracy at $89 \%$. The accuracy that has been achieved using the split system validation model is $67 \%$ as 
training data and $33 \%$ as test data. The other methods have an accuracy rate of between $80 \%$ $88 \%$. This work also calculates the performance of prediction methods based on sensitivity, specificity, precision, and F-Measures, where the VLRAKN method is the method that has the highest performance measure on all of these measures.

Multinomial Nave Bayes and Decision Trees are two of the most popular and easy to understand classification methods. The Multinomial Naïve Bayes method uses Bayes' theorem in determining its decisions, where each predictor variable must be categorical following a multinomial distribution if there are more than two categories, and a binomial distribution if there are only two categories (Chen \& Fu, 2018). The Decision Tree method uses a tree structure representation where each node describes the variable, the branch describes the value of the variable, and the leaf describes the class. Decision Trees have a fairly high level of accuracy in various cases (Santoso, 2012).

This study discusses risk prediction for coronary artery disease, which can also be called early detection of heart disease, by implementing two statistical learning methods, namely Multinomial Naïve Bayes and Decision Trees with 10-fold cross-validation as a model validation technique. The novelty in this study is a technique for categorizing five numerical variables in research data, namely age (years), cholesterol levels (mg/dl), fasting blood sugar levels $(\mathrm{mg} / \mathrm{dl})$, maximum heart rate $(\mathrm{bpm})$, and old peak $(\mathrm{mV})$ conducted with different criteria from Purushottam et al., (2016), as well as David and Belcy, (2018) and Riani et al., (2019). The categorization of the five numerical variables is based on valid references that specifically discuss these numerical variables. In addition, in this study, the missing data was not included in the data processing because the majority of the data was incomplete. The performance of the two statistical learning methods is then measured based on the level of accuracy, sensitivity, specificity, precision, and negative predictive value (NPV). This performance measure is very important in practice, because it guides the choice of learning method or model, and provides a measure of the quality of the method or model that is finally selected, including for independent data (Hastie et al., 2009).

\section{METODE}

The steps in this study are presented in Figure 1. The research data is Heart Disease data from the Cleveland Clinic Foundation, which was donated as public data to the Center for Machine Learning and Intelligent Systems (https://archive.ics.uci.edu/ $\mathrm{ml} /$ datasets/Heart+Disease). The data consists of a target variable (dependent) and a predictor variable (independent). The target variable is the health status of patients related to heart 
disease, which consists of two categories, namely patients who have heart disease and patients who do not have heart disease. The predictor variables consisted of two personal data variables in the form of age and gender and 11 data variables from medical examination results.

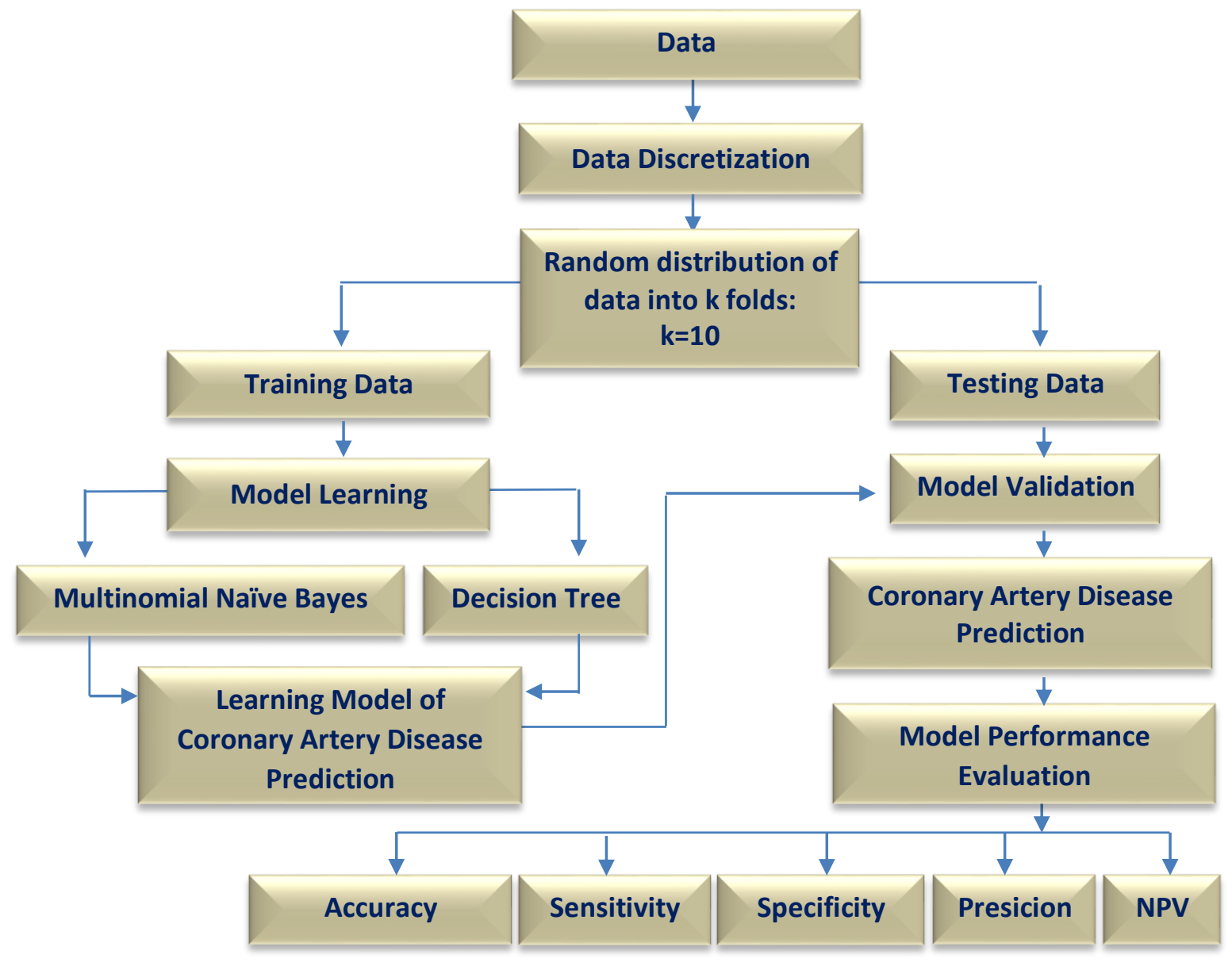

Figure 1. Research Methodology

The dependent variable is denoted as $Y_{j}, j=$ no, yes, where "no" represents patients who do not have heart disease and "yes" represents patients who have heart disease. The thirteen independent variables are each denoted as $X_{i}, i=1,2,3, \cdots, 13$ namely age $\left(X_{1}\right)$, sex $\left(X_{2}\right)$, types of chest pain $\left(X_{3}\right)$, blood pressure at rest $\left(X_{4}\right)$, cholesterol level $\left(X_{5}\right)$, fasting blood sugar level $>120 \mathrm{mg} / \mathrm{dl}\left(X_{6}\right)$, ECG results at rest $\left(X_{7}\right)$, maximum heart rate $\left(X_{8}\right)$, exercise causes anginatype chest pain $\left(X_{9}\right)$, oldpeak or ST segment obtained from exercise relative to rest $\left(X_{10}\right)$, ST segment slope $\left(X_{11}\right)$, number of major pulses stained by fluoroscopy $\left(X_{12}\right)$ and thalassemia $\left(X_{13}\right)$. Of the thirteen explanatory variables, there are 5 numerical variables and 7 categorical variables. Both the Multinomial Naïve Bayes and Decision Tree methods require that all variables be categorical types, so that the five numeric variables are categorized first. The 
complete details of the response variables and the thirteen explanatory variables are presented in Table 1.

Tabel 1. Data Penelitian

\begin{tabular}{|c|c|c|}
\hline Variable & Data Type & Information \\
\hline$X_{1}$ & Numeric & 29-77 years \\
\hline$X_{2}$ & Categorical & male; female \\
\hline$X_{3}$ & Categorical & $\begin{array}{l}\text { typical angina; atypical angina; non-anginal pain; } \\
\text { asymptomatic }\end{array}$ \\
\hline$X_{4}$ & Numeric & $94-200 \mathrm{~mm} / \mathrm{Hg}$ \\
\hline$X_{5}$ & Numeric & $126-564 \mathrm{mg} / \mathrm{dl}$ \\
\hline$X_{6}$ & Categorical & false; true \\
\hline$X_{7}$ & Categorical & $\begin{array}{l}\text { normal; have ST-T wave abnormalities; demonstrate left } \\
\text { ventricular hypertrophy according to estes criteria }\end{array}$ \\
\hline$X_{8}$ & Numeric & $71-202 \mathrm{bpm}$ \\
\hline$X_{9}$ & Categorical & No; Yes \\
\hline$X_{10}$ & Numeric & $0-6,2 \mathrm{mV}$ \\
\hline$X_{11}$ & Categorical & leaning up; flat; slightly sloping \\
\hline$X_{12}$ & Categorical & $0 ; 1 ; 2 ; 3$ \\
\hline$X_{13}$ & Categorical & $\begin{array}{l}\text { three (normal); six (permanent disability); seven (temporary } \\
\text { disability) }\end{array}$ \\
\hline$Y$ & Categorical & no; yes \\
\hline
\end{tabular}

In the process of predicting, the data is divided into two parts, namely training data and test data. The training data is used to build a prediction/classification learning model, while the test data is used to validate the previously built model. The model validation method using a cross-validation technique with many folds was chosen in this study because it has a small bias (Rodri'guez et al, 2010). The division refers to (Burger, 2018) as presented in Figure 2.

\begin{tabular}{llllllllll}
\hline test & train & train & train & train & train & train & train & train & train \\
\hline train & test & train & train & train & train & train & train & train & train \\
\hline train & train & test & train & train & train & train & train & train & train \\
\hline train & train & train & test & train & train & train & train & train & train \\
\hline train & train & train & train & test & train & train & train & train & train \\
\hline train & train & train & train & train & test & train & train & train & train \\
\hline train & train & train & train & train & train & test & train & train & train \\
\hline train & train & train & train & train & train & train & test & train & train \\
\hline train & train & train & train & train & train & train & train & test & train \\
\hline train & train & train & train & train & train & train & train & train & test \\
\hline
\end{tabular}

Figure 2. Splitting Training and Test Data for 10-Fold Cross Validation 
The statistical learning methods used to build a predictive model of heart disease status in this work are the Multinomial Naïve Bayes method (Pan et al, 2018) and the Decision Tree (Han et al., 2012). These two methods are often successful in carrying out prediction/classification tasks with a high degree of accuracy (Retnasari and Rahmawati, 2017).

The Multinomial Naïve Bayes method works based on the Bayes theorem, which determines the maximum posterior probability of each observation obtained as the product of the prior probability and the likelihood probability. Let $P\left(X_{k} \mid Y_{y e s}\right)$ and $P\left(X_{k} \mid Y_{n o}\right)$ Let $\mathrm{A}$ and $\mathrm{B}$ are the likelihood probabilities of the occurrence/diagnosis of cardiac arrest and no, respectively, which are written as,

$$
\begin{aligned}
& P\left(X_{k} \mid Y_{\text {yes }}\right)=\frac{\sum_{c}^{m} n_{c}\left(X_{k} \mid Y_{\text {yes }}\right)+1}{n\left(X_{k} \mid Y_{\text {yes }}\right)+m} \\
& P\left(X_{k} \mid Y_{\text {no }}\right)=\frac{\sum_{c}^{m} n_{c}\left(X_{k} \mid Y_{\text {no }}\right)+1}{n\left(X_{k} \mid Y_{\text {no }}\right)+m}
\end{aligned}
$$

Posterior probability for $Y_{j}, j$ is,

$$
P\left(Y_{j} \mid X_{1}, \cdots, X_{d}\right)=\arg \max P\left(Y_{j}\right) \prod_{k=1}^{d} P\left(X_{k} \mid Y_{j}\right)
$$

where the prior probability of each group is defined as,

$$
\begin{aligned}
& P\left(Y_{\text {yes }}\right)=\frac{\sum_{k=1}^{d} n\left(X_{k} \mid Y_{\text {yes }}\right)+1}{n+g} \\
& P\left(Y_{\text {no }}\right)=\frac{\sum_{k=1}^{d} n\left(X_{k} \mid Y_{n o}\right)+1}{n+g}
\end{aligned}
$$

For the group of patients diagnosed with heart disease, $n_{c}\left(X_{k} \mid Y_{y e s}\right)$ is the number of patients diagnosed with heart disease in variable $X_{k}$ with category $c, n\left(X_{k} \mid Y_{y e s}\right)$ is the number of patients diagnosed with heart disease in variable $X_{k}, n\left(Y_{y e s}\right)$ is the number of patients diagnosed with heart disease, $m$ is the number of categories in the variable $X_{k}$, and $g$ is the total number of groups in the study.

The Decision Tree is a classification method that has a tree structure such as a flow chart (Figure 3), where each internal node shows a test on a variable, each branch shows the results of the test, and a leaf node shows the results of the test node (classes), while the topmost node is called the root node. The concept of a decision tree is to partition data based on the highest 
gain value so that a decision tree is formed which is then used to form decision rules using IFTHEN logic (Han et al., 2012).

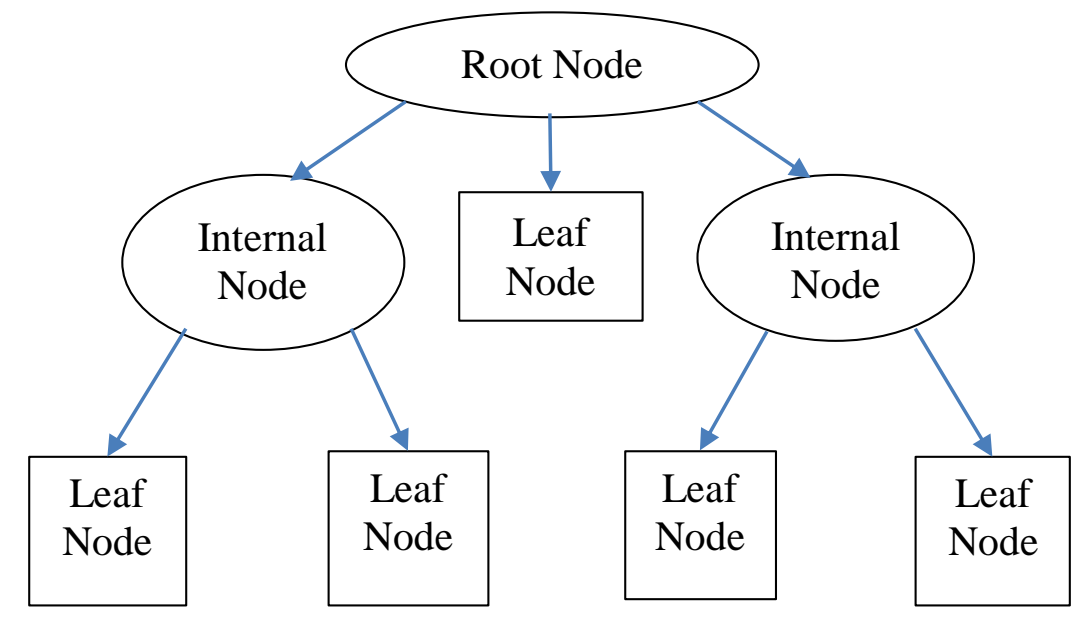

Figure 3. Decision Tree Model

The main steps in constructing a decision tree are: first, selecting a variable as the root; second, loading the branch for each value; third, dividing each branch into classes; and fourth, repeating the process for each branch until all cases in each branch have the same class. The basis for choosing a variable as the root is the highest information gain value of all variables. Before getting the highest gain value, first calculate the entropy value of all values in the variable. Entropy acts as a parameter to measure the variance of the sample data. After the entropy value in the sample data is known, the most influential variable will be a measure of classifying the data. This measure is referred to as information gain.

Entropy and Information Gain are obtained using (6) - (8), respectively.

$$
\begin{aligned}
& \text { Entropy }(S)=\sum_{i=1}^{k_{S}}-P_{i} \log _{2} P_{i} \\
& \operatorname{Entropy}\left(S_{c}\right)=\sum_{c=1}^{k_{X}}-P_{c} \log _{2} P_{c} \\
& \text { Information Gain }(S, X)=\operatorname{Entropy}(S)-\sum_{c=1}^{k_{X}} \frac{\left|S_{c}\right|}{|S|} \operatorname{Entropy}\left(S_{c}\right)
\end{aligned}
$$


where $S, k_{s}, S_{c} k_{X}, P_{i}$, and $P_{c}$ respectively as the total number of patients, the number of patient groups, the total number of patients in the $c$-th category of the predictor variable $X$, the number of categories in the variable $X$, the prior probability in the $i$-th group of the predictor variable $X$, and the prior probability in the $c$-th category of the predictor variable $X$.

Furthermore, after the prediction results of heart disease status using the Multinomial Naïve Bayes and Decision Tree methods were obtained, the performance of the two methods was evaluated. Regarding medical data, the performance of prediction results can be evaluated using the level of accuracy, sensitivity, specificity, precision, and negative predictive value (NPV) (Maniruzzaman et al., 2017) as shown in equation (9) - (13) based on the confusion matrix as in Table 2 (Gathak, 2017); (Burgers, 2018).

Table 2. Confusion Matrix

\begin{tabular}{|c|c|c|}
\hline \multirow{2}{*}{ Predict } & \multicolumn{2}{|c|}{ Actual } \\
\hline & Yes & No \\
\hline Yes & True Positive (TP) & False Positive (FP) \\
\hline No & False Negative (FN) & True Negative (TP) \\
\hline
\end{tabular}

$$
\begin{aligned}
& \text { Accuracy }=\frac{\mathrm{TP}+\mathrm{TN}}{\mathrm{TP}+\mathrm{FP}+\mathrm{FN}+\mathrm{TN}} \\
& \text { Sensitivity }=\frac{\mathrm{TP}}{\mathrm{TP}+\mathrm{FN}} \\
& \text { Specificity }=\frac{\mathrm{TN}}{\mathrm{FP}+\mathrm{TN}} \\
& \text { Precision }=\frac{\mathrm{TP}}{\mathrm{TP}+\mathrm{FP}} \\
& \text { Negative Prediction Value }(\mathrm{NPV})=\frac{\mathrm{TN}}{\mathrm{FN}+\mathrm{TN}}
\end{aligned}
$$

\section{RESULT}

This research begins by discretizing predictor variable data of numeric type based on references as presented in Table 3 . Next, divide the data into 10-fold randomly and then separate them as training data and test data as illustrated in Figure 1. Table 4 presents the composition of each training (learning) data and test data for model development and validation. 
Table 3. Numerical Variable Discretization

\begin{tabular}{|c|c|c|}
\hline Variabel & Diskritisasi & Sumber \\
\hline$X_{1}$ & $\begin{array}{l}<40 \text { years } \\
40-64 \text { years } \\
\geq 65 \text { years }\end{array}$ & $\begin{array}{l}\text { WHO, } 2019 \\
\text { Woodward et al., } 2012\end{array}$ \\
\hline$X_{4}$ & $\begin{array}{l}90-119 \mathrm{~mm} \text { hg (normal); } \\
120-139 \mathrm{~mm} \text { hg (pra-hipertentioni); } \\
\geq 140 \mathrm{~mm} \text { hg (hipertention) }\end{array}$ & Borghi et al. (2003) \\
\hline$X_{5}$ & $\begin{array}{l}<200 \text { (normal); } \\
200-239 \text { (high limit) } \\
\geq 240 \text { (high) }\end{array}$ & $\begin{array}{l}\begin{array}{l}\text { Third Report of the } \\
\text { Cholesterol Eational } \\
\text { (NCEP), } 2001\end{array} \\
\end{array}$ \\
\hline$X_{8}$ & $\begin{array}{l}\leq 100 \text { (normal); } \\
>100 \text { (takikarbi) }\end{array}$ & Palatini, 1999 \\
\hline$X_{10}$ & $\begin{array}{l}<3,2(\text { no }) \\
\geq 3,2 \text { (yes) }\end{array}$ & Riani et al., 2019 \\
\hline
\end{tabular}

Table 4. Composition of Training and Test Data

\begin{tabular}{lcccccccccc}
\hline \multicolumn{10}{c}{ Test Data (One-fold) } \\
\hline Grup & $\mathbf{1}$ & $\mathbf{2}$ & $\mathbf{3}$ & $\mathbf{4}$ & $\mathbf{5}$ & $\mathbf{6}$ & $\mathbf{7}$ & $\mathbf{8}$ & $\mathbf{9}$ & $\mathbf{1 0}$ \\
\hline Yes & 15 & 13 & 16 & 12 & 13 & 8 & 10 & 12 & 12 & 9 \\
\hline No & 12 & 14 & 11 & 15 & 14 & 19 & 17 & 15 & 15 & 18 \\
\hline Total & 27 & 27 & 27 & 27 & 27 & 27 & 27 & 27 & 27 & 27 \\
\hline & \multicolumn{1}{c}{ Learning Data (Nine-fold) } & & & \\
\hline Grup & $\mathbf{1}$ & $\mathbf{2}$ & $\mathbf{3}$ & $\mathbf{4}$ & $\mathbf{5}$ & $\mathbf{6}$ & $\mathbf{7}$ & $\mathbf{8}$ & $\mathbf{9}$ & $\mathbf{1 0}$ \\
\hline Yes & 105 & 107 & 104 & 108 & 107 & 112 & 110 & 108 & 108 & 111 \\
\hline No & 138 & 136 & 139 & 135 & 136 & 131 & 133 & 135 & 135 & 132 \\
\hline Total & 243 & 243 & 243 & 243 & 243 & 243 & 243 & 243 & 243 & 243 \\
\hline
\end{tabular}

Table 5 presents a learning model using the Multinomial Naive Bayes method for the first learning data with observations of 105 patients who have heart disease and 108 who do not have heart disease (healthy). The learning model using the Decision Tree method for the first learning data with the same observations as using the Multinomial Naive Bayes method is presented in Figure 4. 
Table 5. The First Learning Model using Multinomial Naive Bayes

\begin{tabular}{ccccccccc}
\hline \multirow{2}{*}{$\boldsymbol{Y}$} & $\boldsymbol{P}(\boldsymbol{Y})$ & \multicolumn{3}{c}{$\boldsymbol{P}\left(\boldsymbol{X}_{\mathbf{1}} \mid \boldsymbol{Y}\right)$} & \multicolumn{3}{c}{$\boldsymbol{c} \boldsymbol{P}\left(\boldsymbol{X}_{\mathbf{1 3}} \mid \boldsymbol{Y}\right)$} \\
\cline { 3 - 8 } & & $\begin{array}{c}<\mathbf{4 0} \\
\text { years }\end{array}$ & $\begin{array}{c}\mathbf{4 0 - 6 4} \\
\text { years }\end{array}$ & $\begin{array}{c}\mathbf{2} \mathbf{6 5} \\
\text { years }\end{array}$ & & normal & $\begin{array}{c}\text { permanent } \\
\text { disability }\end{array}$ & $\begin{array}{c}\text { temporary } \\
\text { disability }\end{array}$ \\
\hline Jantung & 0.43 & 0.06 & 0.80 & 0.14 & $\cdots$ & 0.78 & 0.05 & 0.17 \\
\hline Tidak & 0.57 & 0.05 & 0.80 & 0.15 & $\cdots$ & 0.31 & 0.07 & 0.62 \\
\hline
\end{tabular}

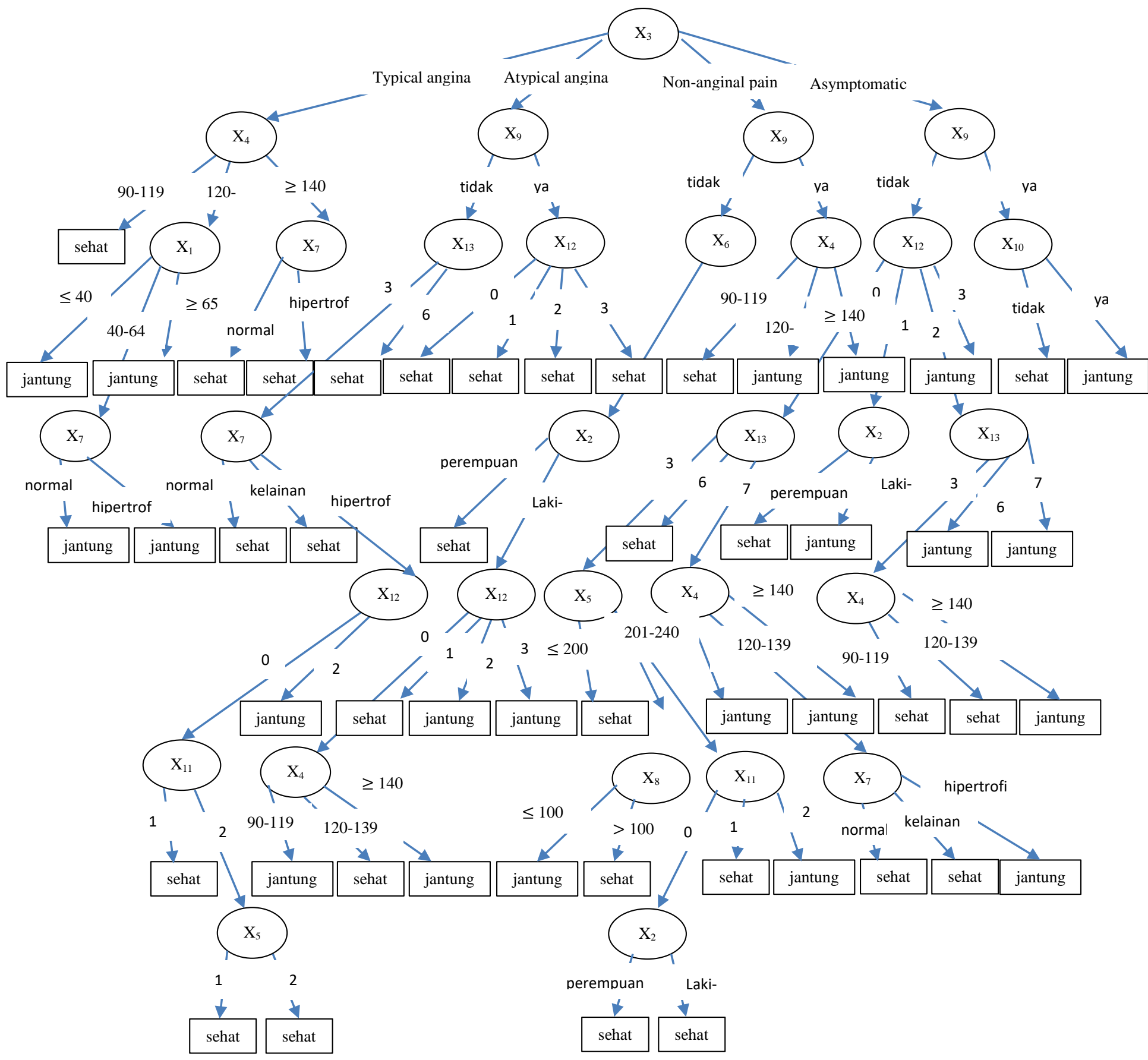

Figure 4. Decision Tree method learning model for the first learning data 
e-ISSN : 2656-7245 Coronary Artery Disease Prediction Using Decision Trees and Multinomial ...

Furthermore, Table 6 presents the prediction results for fold 1 to fold 10 using the Multinomial Naive Bayes method based on each learning model. Prediction results using the Decision Tree method for fold 1 to fold 10 based on each learning model are presented in Table $\underline{7 .}$

Tab1e 6. Prediction of Heart Disease Status using Multinomial Naïve Bayes

\begin{tabular}{cccccc}
\hline Testing & Accuracy & Sensitivity & Specificity & Precision & NPV \\
\hline Fold 1 & 88.89 & 93.33 & 83.33 & 87.50 & 90.91 \\
\hline Fold 2 & 92.59 & 92.31 & 92.86 & 92.31 & 92.86 \\
\hline Fold 3 & 92.59 & 87.50 & 100.00 & 100.00 & 84.62 \\
\hline Fold 4 & 85.19 & 75.00 & 93.33 & 90.00 & 82.35 \\
\hline Fold 5 & 81.48 & 69.23 & 92.86 & 90.00 & 76.47 \\
\hline Fold 6 & 85.19 & 50.00 & 100.00 & 100.00 & 82.61 \\
\hline Fold 7 & 100.00 & 100.00 & 100.00 & 100.00 & 100.00 \\
\hline Fold 8 & 92.59 & 83.33 & 100.00 & 100.00 & 88.24 \\
\hline Fold 9 & 100.00 & 100.00 & 100.00 & 100.00 & 100.00 \\
\hline Fold 10 & 100.00 & 100.00 & 100.00 & 100.00 & 100.00 \\
\hline Mean & 91.85 & 85.07 & 96.24 & 95.98 & 89.80 \\
\hline $\begin{array}{l}\text { Standard } \\
\text { Deviation }\end{array}$ & 6.72 & 16.26 & 5.60 & 5.31 & 8.41 \\
\hline
\end{tabular}

Prediction results using the Decision Tree method for fold 1 to fold 10 based on each learning model are presented in Table 7.

Tab1e 7. Prediction of Heart Disease Status using Decision Tree Method

\begin{tabular}{cccccc}
\hline Testing & Accuracy & Sensitivity & Specificity & Precision & NPN \\
\hline Fold 1 & 100.00 & 100.00 & 100.00 & 100.00 & 100.00 \\
\hline Fold 2 & 100.00 & 100.00 & 100.00 & 100.00 & 100.00 \\
\hline Fold 3 & 100.00 & 100.00 & 100.00 & 100.00 & 100.00 \\
\hline Fold 4 & 100.00 & 100.00 & 100.00 & 100.00 & 100.00 \\
\hline Fold 5 & 100.00 & 100.00 & 100.00 & 100.00 & 100.00 \\
\hline Fold 6 & 100.00 & 100.00 & 100.00 & 100.00 & 100.00 \\
\hline Fold 7 & 100.00 & 100.00 & 100.00 & 100.00 & 100.00 \\
\hline Fold 8 & 100.00 & 100.00 & 100.00 & 100.00 & 100.00 \\
\hline Fold 9 & 96.30 & 100.00 & 93.33 & 92.31 & 100.00 \\
\hline Fold 10 & 100.00 & 100.00 & 100.00 & 100.00 & 100.00 \\
\hline Mean & 99.63 & 100.00 & 99.33 & 99.23 & 100.00 \\
\hline $\begin{array}{c}\text { Standard } \\
\text { Deviation }\end{array}$ & 1.17 & 0.00 & 2.11 & 2.43 & 0.00 \\
\hline
\end{tabular}




\section{DISCUSSION}

Prediction of coronary artery disease has been carried out using many methods. This study proposes two statistical learning methods to predict coronary artery disease, namely Multinomial Naïve Bayes and Decision Trees. Both of these methods require that all variables be categorical type so that numerical variables in the research data are discretized first to obtain categorical type variables. The results of the discretization of the five numerical variables presented in Table 3 show that each age variable $\left(X_{1}\right)$, blood pressure at rest $\left(X_{4}\right)$, and cholesterol levels $\left(X_{5}\right)$ has three categories, while each variable maximum heart rate $\left(X_{8}\right)$ and oldpeak or ST segment obtained from exercise relative to rest $\left(X_{10}\right)$ has two categories. The results of this discretization are different from those in Purushottam et al., (2016), David and Belcy, (2018), Riani et al., (2019) (only the variable $X_{10}$ is the same), as well as Chowdary et al. (2020). This study also did not involve missing data like Purushottam et al., (2016).

Randomly dividing the data into 10-folds and then separating them as training data for model learning and test data to validate the model as presented in Table 4 shows that each fold has the same size, both training data, which contains nine folds, and test data. which contains one-fold. However, the size of the data on being diagnosed with heart disease and not having heart disease is not exactly the same. In the 1 st and 3rd fold data, the size of the data diagnosed as having heart disease is larger than the data size diagnosed as not having heart disease, while in other folds it is the opposite.

Model learning using the Multinomial Naïve Bayes method shows that each variable has a different probability (likelihood) in each category as presented in Table 5 for the 1st learning data. The same thing happened to the other nine learning data. In the learning model using the Decision Tree method as shown in Figure 4, the variable that becomes the root node is the type of chest pain variable $\left(X_{3}\right)$ which has four categories where each of the four categories has a size different internal nodes and leaves. The typical angina category has the smallest internal node and leaf size compared to the atypical angina, non-anginal pain, and asymptomatic categories, while the asymptomatic category has the largest size.

The performance measures of the two methods as presented in Table 6 and Table 7 show that the average of the five performance measures and the standard deviation of the 10-fold test data as validated using the Decision Tree method is higher than the Multinomial Naïve Bayes method. In the Decision Tree method, the five performance measures at nine-fold are all 100\%. In the 9th fold, not all of the performance measures are $100 \%$, so the average of the five performance measures is $99.63 \%$ accuracy, $100 \%$ sensitivity, $99.33 \%$ specificity, $99.23 \%$ 
precision, and 100\% NPV. In the Multinomial Naïve Bayes method, only fold 7, fold 9, and fold 10 have five performance measures that are all 100\%. The average performance measures of the five measures for fold 1 to fold 10 in a row, namely accuracy, sensitivity, specificity, precision, and NPN are 91.85\%, 85, 07\%, 96.24\%, 95.98\%, and 89.90\%, while the standard deviations are $6.72 \%, 16.26 \%, 5.6 \%, 5.31 \%$, and $8.41 \%$, respectively. Overall, both the mean and standard deviation of all folds in this study indicate that the Multinomial Naïve Bayes method is not better than the Decision Tree method in predicting coronary artery disease. The results obtained in this study are also better than those of Purushottam et al. (2016), who obtained the highest level of accuracy of $86.3 \%$ with the Efficient System method, one of the several methods it uses. The results of this study are also better than David and Belcy (2018), which obtained a precision of $81 \%$ with the Random Forest method. Likewise, when compared with Chowdary et al. (2020) who obtained accuracy, sensitivity, specificity, and precision of $89 \%, 86 \%, 91 \%$, and $91.6 \%$, respectively, in predicting coronary artery disease using the VLRNAK ensemble method. Several other studies using the same dataset as Normawati and Winiarti, (2017), Retnasari and Rahmawati, (2017), Indrajani et al., (2018), Aini et al., (2018), Aulia, (2018), Riani et al., (2019), and Pangaribuan et al., (2019) have accuracy that is not better than our work.

\section{CONCLUSION}

This study succeeded in predicting the risk of coronary artery disease using two statistical learning methods, namely Multinomial Naïve Bayes and Decision Trees. Numerical variables in the research data were discretized to obtain categorical variables by referring to valid sources. The learning model validation technique used is 10 -fold cross validation. The results showed that the performance measures of the Decision Tree method were more consistent, higher, and had a relatively smaller standard deviation than the Multinomial Naïve Bayes method. These results indicate that the performance of the Decision Tree method is better than the Multinomial Naïve Bayes method in predicting coronary artery disease. The results of this study also indicate that differences in reference in discretizing numerical variables can affect the performance of the method in predicting the risk of coronary artery disease. 


\section{REFERENSI}

Aini, S. H. A., Sari, Y. A., dan Arwan, Achmad. (2018). Seleksi Fitur Information Gain untuk Klasifikasi Penyakit Jantung Menggunakan Kombinasi Metode K-Nearest Neighbor dan Naïve Bayes. Jurnal Pengembangan Teknologi Informasi dan Ilmu Komputer Vol. 2, No. 9.

Alcalá-Fdez, J., Sánchez, L., García, M.J. del Jesus, S., Ventura, S., Garrell, J.M., Otero, J., Romero, C., Bacardit, J., Rivas, V.M., Fernández, J.C., Herrera, F. (2009). KEEL: A Software Tool to Assess Evolutionary Algorithms to Data Mining Problems. Soft Computing 307-318

Alcalá-Fdez, J., Fernandez, A., Luengo, J., Derrac, J., García, S., Sánchez, L., Herrera, F. (2011). KEEL Data-Mining Software Tool: Data Set Repository, Integration of Algorithms and Experimental Analysis Framework. Journal of Multiple-Valued Logic and Soft Computing 17:2-3 (2011) 255-287.

Aulia, W. (2018). Sistem Pakar Diagnosa Penyakit Jantung Koroner Dengan Metode Probabilistic Fuzzy Decision Tree. Jurnal Sains dan Informatika. 4(12):106-117.

Bhatia, Sujata K. (2010). Biomaterials for clinical applications (Online-Ausg. ed.). New York: Springer. p. 23. ISBN 9781441969200. Archived from the original on 10 January 2017.

Borghi, C., Dormi, A., L’Italien, G., Lapuerta, P., Franklin, S.S., Collatina, S., Gaddi, A. (2003). The Relationship Between Systolic Blood Pressure and Cardiovascular Risk-Results of the Brisighella Heart Study. The Journal of Clinical Hypertension, Vol. V, No. 1, January/February.

Burger, S. V. (2018). Introduction to Machine Learning with R: Rigorous Mathematical Analysis. Oreilly.

Chen, H., Fu, D. (2018). An Improved Naïve Bayes Classifier for Large Scale Text. Advances in Intelligent Systems Research, volume 146, pp.33-36.

Chowdary, G., J., Suganya, G., Premalatha, M. (2020). Effective Prediction of Cardiovascular Disease Using Cluster of Machine Learning Algorithms. Journal of Critical Reviews, Vol.7 (18), $2192-2201$.

David, H. B. F., Belcy, S. A. (2018). Heart Disease Prediction using Data Mining Techniques. ICTACT Journal on Soft Computing 9 (1), 1817 - 1823, October.

Gathak, A. (2017). Machine Learning with R. Springer.

Han, J., Kamber, M., dan Pei, J. (2012). Data Mining: Concept and Techniques, Third Edition. Waltham: Morgan Kaufmann.

Hastie, T., Tibshirani, R., Friedman, J.H. (2009). The Elements of Statistical Learning: Data Mining, Inference, and Prediction. California: Springer. 
Indrajani, Bahana, R., Kosala., R, Haryadi, Y. (2018). Aplikasi Informasi Kesehatan dan Diagnosa Penyakit Jantung Berbasis Android, Seminar Nasional Teknologi Informasi, Komunikasi dan Industri (SNTIKI-10), November.

Maniruzzaman, M., Kumar, N., Abedin, M. M., Islam, M. S., Suri, H.S., El-Baz, A. S., Suri, J.S. (2017). Comparative Approaches for Classification of Diabetes Mellitus Data: Machine Learning Paradigm. Computer Methods and Programs in Biomedicine, vol. 152, pp. 23-34, 2017, doi: 10.1016/j.cmpb.2017.09.004.

Mendis, S., Puska, P., Norrving, B. (2015). Global atlas on cardiovascular disease prevention and control, 1st ed. Geneva: World Health Organization in collaboration with the World Heart Federation and the World Stroke Organization. pp. 3-18. ISBN 9789241564373.

Normawati, D., dan Winiarti, S. (2017). Seleksi Fitur Menggunakan Penambangan Data Berbasis Variable Precision Rough Set (VPRS) Untuk Diagnosis Penyakit Jantung Koroner. Jurnal Ilmu Teknik Elektro Komputer dan Informatika (JITEKI) Vol. 3, No. 2.

Palatini, P. (1999). Need for a Revision of the Normal Limits of Resting Heart Rate. Hypertension, 33:622-625.

Pan, Y., Gao, H., Lin, H., Liu, Z., Tang, L., Li, S. (2018). Identification of Bacteriophage Virion Proteins Using Multinomial Naïve Bayes with g-Gap Feature Tree. International Journal of Molecular Science, 19, 1779; doi:10.3390/ijms19061779.

Pangaribuan J. J., Tedja, C., dan Wibowo, S. (2019). Perbandingan Metode Algoritma C4.5 Dan Extreme Learning Machine untuk Mendiagnosis Penyakit Jantung Koroner. Informatics Engineering Research and Technology Vol. 1, No.1.

Purushottam, Saxena, K., Sharma, R. (2016). Efficient Heart Disease Prediction System. Procedia Computer Science, 85962 - 969.

Retnasari, T., dan Rahmawati, E. (2017). Diagnosa Prediksi Penyakit Jantung Dengan Model Algoritma Nä̈ve Bayes dan Algoritma C4.5, Konferensi Nasional Ilmu Sosial \& Teknologi (KNiST), pp. 7-12, Maret 2017.

Riani, A., Susianto, Y., Rahman, Nur. (2019). Implementasi Data Mining Untuk Memprediksi Penyakit Jantung Mengunakan Metode Naive Bayes. Journal of Innovation Information Technology and Application, Vol.1, No.01, Desember, pp.25-34, DOI: 10.35970/jinita.v1i01.64.

Rodri'guez, J. D., Rez, A. P., Lozano, J. A. (2010). Sensitivity Analysis of k-Fold Cross Validation in Prediction Error Estimation. IEEE Transaction on Pattern Analysis and Machine Intelligence, vol. 32, no. 3, pp. 569-575, doi: 0162-8828/10/\$26.00.

Santoso, H. 2012. Analisis Dan Prediksi Pada Perilaku Mahasiswa Diploma Untuk Melanjutkan Studi Ke Jenjang Sarjana Menggunakan Teknik Decision Tree dan Support Vektor Machine. Tesis, Universitas Sumatera Utara. 
Third Report of the National Cholesterol Education Program (NCEP). (2001). Expert Panel on Detection, Evaluation, and Treatment of High Blood Cholesterol in Adults (Adult Treatment Panel III). Executive Summary. National Heart, Lung, and Blood Institute. National Institutes of Health, United State, No. 01-3670, May.

Woodward, M., Webster, R., Murakami, Y., Barzi, F., Lam, T-H., Fang, X., Suh, I., Batty, G. D., Huxley, R., Rodgers, A. (2014). The Association Between Resting Heart Rate, Cardiovascular Disease and Mortality: Evidence From 112,680 Men and Women in 12 Cohorts. European Journal of Preventive Cardiology, Vol 21 (6), 719-726.

World Health Organization (WHO), (2019). Cardiovascular diseases (CVDs). Diambil dari https://www. who.int/card iovascular_diseases/en/. [Accessed: 24-Des-2020]. 